\title{
The Lure of an Irish Catholic Diocesan Seminary
}

\author{
Brian Conway
}

Received: 28 February 2014/ Accepted: 4 March 2014/Published online: 13 March 2014

(C) Religious Research Association, Inc. 2014

\section{Study}

In 2010 the Council for Research and Development, the research entity of the Irish Catholic Bishops' Conference, commissioned a study to investigate the seminary routes, seminary experiences, and social backgrounds of seminarians for the Catholic diocesan priesthood in the pontifical university at St. Patrick's College, Maynooth, the only still operating Catholic seminary in the Republic of Ireland. The research, which was completed in early 2014, was based primarily on a selfadministered questionnaire distributed to 65 seminarians during the 2012-2013 academic year. Thirty-six completed questionnaires were successfully returned, giving a response rate of 55\%. This was supplemented by a review of the extant literature on Catholic vocations and prior research on seminarians in general and Irish seminarians in particular.

\section{Findings}

The average age at which seminarians first thought about becoming a priest was 13 . About half of seminarians identified a priest as the person who most encouraged them to opt for the seminary, confirming the importance of social factors in promoting vocations. Seminary open days and pilgrimages to Catholic sacred sites were the most important religious occasions increasing the appeal of the seminary. Internet-based sources associated with new social media were more important information sources for would-be seminarians than print-based materials. The average number of in-person meetings a seminarian had with a vocations director

B. Conway ( $\bowtie)$

Department of Sociology, National University of Ireland, Maynooth, Maynooth, Co. Kildare,

Republic of Ireland

e-mail: brian.conway@nuim.ie 
prior to the seminary was 5 . Seminarians tended to be active Catholics prior to entering the seminary, to rate their mothers and grandmothers as more religious than their fathers and grandfathers, and to have been most attracted to the seminary for religiously inspired reasons rather than socially-oriented commitments.

For the majority of seminarians, the seminary is a very positive experience. On a 0-4 scale, seminarians rated each of the human, spiritual, pastoral, and academic components of their training above 3.4. The three greatest challenges of the seminary were: academic training, meeting the high ideals of being a priest, and having adequate financial resources. Celibacy was also ranked among the top few challenges of seminary life. Closeness to God, serving God, and learning about one's faith were the three most important sources of satisfaction associated with the seminary. I also found that seminarians favor structural change in the seminary, such as fostering greater contact with their future diocese.

Seminarians are of many ages rather than being in their late teens or early 20 s, as was common in the past. Ninety-three per cent of respondents had some paid fulltime work experience and $52 \%$ had a primary degree prior to entering the seminary. This means that the majority of today's seminarians are second-career rather than direct-entry seminarians. Forty per cent of respondents came from a rural area. Although today's seminarian tends to come from a family background involving a high level of commitment to Catholic identity, compared to earlier generations fewer seminarians now receive a Catholic education in primary and secondary school. Finally, seminarians come from a family with an average of three children. 